\title{
Association of Estrogen Receptor-Alpha Gene Polymorphism with Pathogenesis of Osteoporosis in Korean Vegetarian Men
}

\author{
So Yeon Kim ${ }^{a}$ Hyun Hee Kim ${ }^{b}$ Chung Mo Nam Hyeon Chang Kim ${ }^{c}$ II Suh ${ }^{c}$ \\ Byung Yong Kang ${ }^{d}$ \\ ${ }^{a}$ Department of Health and Social Welfare, Sahmyook Health College, ${ }^{b}$ Department of Life Science, \\ Sahmyook University, ' Department of Preventive Medicine, Yonsei University College of Medicine, and \\ ${ }^{\mathrm{d}}$ College of Physical Education, Hanyang University, Seoul, Korea
}

\section{Key Words}

Calcaneus · ER1 gene - Male gender • Polymorphism •

Quantitative ultrasound

\begin{abstract}
Objective: The purpose of this study was to investigate the association between two genetic polymorphisms (Pvull and $X b a l$ restriction fragment length polymorphisms, RFLPs) of the estrogen receptor- $\alpha$ (ER1) gene and the quantitative ultrasound (QUS) parameters at the calcaneus. Subjects and Methods: Two hundred and sixty-six Korean vegetarian men, mean age $50.9 \pm 12.0$ years (range $26-80$ ), were studied. Polymorphisms at the ER1 gene sites and the cross-sectional associates of genetic factors with calcaneal QUS parameters including broadband ultrasound attenuation (BUA) and the speed of sound (SOS) were analyzed by RFLPs using polymerase chain reaction. Results: The distribution of Pvull and $X$ bal RFLPs in the ER1 gene was as follows: PP 11.6\%, Pp $47.2 \%$, pp $41.2 \%$, XX $1.2 \%, X \times 24.4 \%$ and $x \times 74.4 \%$. After adjusting for potential confounding factors such as age and body mass index, two genetic polymorphisms of the ER1 gene were independently associated with BUA, SOS and stiffness index at the calcaneus of our subjects. The QUS measurements of the subjects with the $x x$ genotype were
\end{abstract}

higher than those of the subjects with an Xx genotype, while the QUS measurements of the subjects with a Pp genotype were significantly lower than those of the subjects with PP or pp genotypes $(p<0.05)$. Conclusion: The results suggest that the Pvull and Xbal RFLPs of the ER1 gene may be genetic factors that affect QUS at the calcaneus.

Copyright $\odot 2010$ S. Karger AG, Basel

\section{Introduction}

Osteoporosis is an important health problem worldwide, and the prevention of osteoporotic fracture depends upon early identification and intervention. Familial and twin studies indicate that there is a strong genetic component in the etiology of osteoporosis [1]. To identify the genes involved in osteoporosis, the candidate genes encoding for the proteins in bone metabolism should be investigated.

Although bone mineral density (BMD) is a major risk factor for osteoporotic fracture as well as osteoporosis, quantitative ultrasound (QUS) parameters at the calcaneus have recently been found to predict osteoporotic fractures independent of BMD [2]. Thus, the genes responsible for regulating these phenotypes, such as BMD

\section{KARGER}

Fax +4161306 1234

E-Mail karger@karger.ch

www.karger.com
(C) 2010 S. Karger AG, Basel

$1011-7571 / 10 / 0193-0200 \$ 26.00 / 0$

Accessible online at:

www.karger.com/mpp
Byung Yong Kang, PhD

College of Physical Education

Hanyang University, 17 Haengdang-Dong

Seongdong-Gu, Seoul 133-791 (Korea)

Tel. +82 22290 1463, Fax +82 22290 1464, E-Mail kang1969@empal.com 
Fig. 1. Two genetic polymorphisms in the ER1 gene. a $P v u I I$ polymorphism. Lane M, molecular size marker; lanes 1-2 and 4, Pp genotypes; lane 3, PP genotype; lane 5, pp genotype. $\mathbf{b} \mathrm{XbaI}$ polymorphism. Lane $\mathrm{M}$, molecular size marker; lanes 1 and 4, xx genotypes; lanes 2 and 3, Xx genotypes; lane 5 , XX genotype.

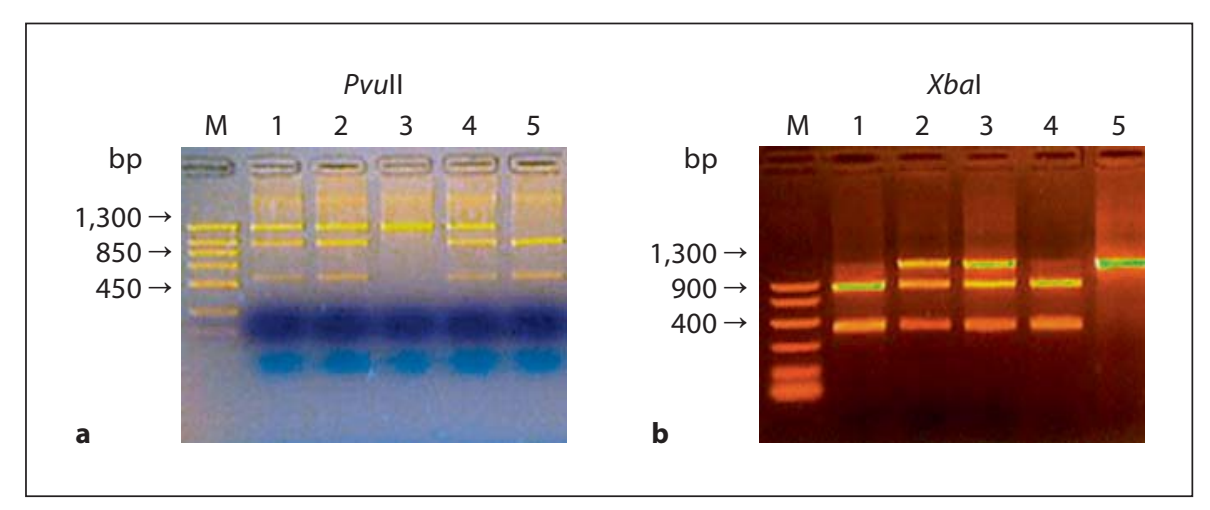

and QUS, may be attractive candidates for osteoporosis.

Estrogen plays an important role in the formation of peak bone mass [3] and in protection against postmenopausal bone loss $[4,5]$. Its effect is mediated by estrogen receptor- $\alpha$ (ER1), a member of the steroid hormone receptor family that functions as a component of the hormone-receptor complex to promote the expression of specific target genes [6]. Thus, ER1 gene has been suggested as a candidate for regulating bone metabolism. The ER1 gene is located within human chromosome 6q25.1 and consists of eight exons separated by seven introns [7]. Kobayashi et al. [8] first reported that two genetic variations (PvuII and $\mathrm{XbaI}$ restriction fragment length polymorphisms, RFLPs) in intron 1 of the ER1 gene were significantly associated with low BMD in Japanese postmenopausal women. However, subsequent studies of the role of the genetic polymorphisms in the ER1 gene have shown conflicting results $[9,10]$. This apparent discrepancy between the studies might be partially explained by the differences in age, site of measurement, and ethnic background of the study subjects. In addition, these studies were mainly performed on postmenopausal women, while similar data on males are scarce.

Therefore, we studied the probable association between the two genetic polymorphisms ( $P v u \mathrm{II}$ and $\mathrm{XbaI}$ RFLPs) of the ER1 gene and QUS at the calcaneus in Korean vegetarian men.

\section{Subjects and Methods}

\section{Subjects}

A total of 601 men were initially enrolled, and after excluding omnivores who consumed unlimited food, 266 healthy Korean vegetarian (strict vegetarians and lacto-ovo vegetarians) men aged $50.9 \pm 12.0$ years (range 26-80) were recruited for the study.
Because the phenotype measured by QUS is a multifactorial trait, it has been known that several environmental factors such as nutrition and exercise contribute significantly to this phenotype [11]. Hence the inclusion criteria were: (1) only males, in order to avoid the effect of menstruation, and (2) vegetarians because nutrition status is an important confounding factor on bone phenotypes, such as BMD and QUS. Exclusion criteria were subjects with diseases and/or taking medications known to affect bone and calcium metabolism. Written informed consent was obtained from all subjects.

\section{Clinical Phenotypes}

Height was measured with a stadiometer and weight evaluated without shoes on a standard clinical balance. Body mass index (BMI) was calculated as weight $(\mathrm{kg})$ divided by height squared $\left(\mathrm{m}^{2}\right)$. Nutrition status and family history of osteoporosis were assessed by a self-administered questionnaire [12]. QUS parameters at the calcaneus were estimated by the measurement of broadband ultrasound attenuation (BUA) and the speed of sound (SOS) using Medilink (Pegasus CDR NO-CE0459, France), and stiffness index (SI) was calculated using the following formula: $\mathrm{SI}=0.67$ $\times \mathrm{BUA}+0.28 \times \mathrm{SOS}-420[13]$.

\section{Genotyping}

Total genomic DNA was purified from buffy coat using a commercial kit (Wizard Genomic DNA purification kit; Promega, Co. Ltd., Madison, Wisc., USA). Polymerase chain reaction (PCR) techniques were used for PvuII and XbaI RFLPs of the ER1 gene. Briefly, a total of $50 \mu \mathrm{l}$ of the reaction mixture containing approximately $150 \mathrm{ng}$ of genomic DNA, $100 \mathrm{ng}$ of each primer, 0.2 $\mathrm{mM}$ of each dNTP, and buffers recommended by the manufacturer was used. The sequences of the primers for the two RFLPs studied were as follows: sense primer, $5^{\prime}$-CTGCCACCCTATCTGTATCTTTTCCTATTCTCC-3' and antisense primer, 5'-TCTTTCTCTGCCACCCTGGCGTCGATTATCTGA-3' [8]. The PCR amplification using this reaction mixture was carried out with an automated thermal cycler. The PCR reaction was heated at $94^{\circ} \mathrm{C}$ for $30 \mathrm{~s}$, cooled to $61^{\circ} \mathrm{C}$ for $40 \mathrm{~s}$, and extended at $72^{\circ} \mathrm{C}$ for $1 \mathrm{~min} 30 \mathrm{~s}$ for a total of 30 cycles. After the PCR reaction, $10 \mu \mathrm{l}$ of the PCR product was digested overnight with 10 units of the proper restriction enzyme $(P v u \mathrm{II}$ or $\mathrm{Xba \textrm {I }})$ at $37^{\circ} \mathrm{C}$. The digested amplified product was size-fractionated after $1 \%$ agarose gel electrophoresis in $1 \times$ TAE buffer for 20 min along with a molecular size 
Table 1. Characteristics of the 266 subjects

\begin{tabular}{|c|c|c|c|}
\hline \multirow[t]{2}{*}{ Parameters } & \multirow[t]{2}{*}{ Category } & \multicolumn{2}{|c|}{ Subjects } \\
\hline & & $\mathrm{n}$ & $\%$ \\
\hline Age, years & $\begin{array}{l}20-29 \\
30-39 \\
40-49 \\
50-59 \\
60-69 \\
\geq 70 \\
\text { Mean }\end{array}$ & $\begin{array}{r}3 \\
61 \\
51 \\
75 \\
58 \\
18 \\
5\end{array}$ & $\begin{array}{r}1.1 \\
22.9 \\
19.2 \\
28.2 \\
21.8 \\
6.8 \\
2.0\end{array}$ \\
\hline BMI, kg/m² & $\begin{aligned}<20 \\
20-24 \\
25-30 \\
>30 \\
\text { Mean }\end{aligned}$ & $\begin{array}{r}38 \\
176 \\
50 \\
2\end{array}$ & $\begin{array}{r}14.3 \\
66.2 \\
18.8 \\
0.7 \\
2.7\end{array}$ \\
\hline $\mathrm{BUA}, \mathrm{dB} / \mathrm{MHz}$ & $\begin{array}{l}<60 \\
\quad 60-70 \\
>70 \\
\text { Mean }\end{array}$ & $\begin{array}{r}95 \\
147 \\
24\end{array}$ & $\begin{array}{r}35.7 \\
55.3 \\
9.0 \\
5.5\end{array}$ \\
\hline $\mathrm{SOS}, \mathrm{m} / \mathrm{s}$ & $\begin{array}{l}<1,600 \\
\quad 1,600-1,700 \\
>1,700 \\
\text { Mean }\end{array}$ & $\begin{array}{r}36 \\
198 \\
32 \\
1,6\end{array}$ & $\begin{array}{r}13.5 \\
74.5 \\
12.0 \\
43.5\end{array}$ \\
\hline Stiffness & $\begin{array}{l}<70 \\
70-79 \\
80-89 \\
\geq 90 \\
\text { Mean }\end{array}$ & $\begin{array}{r}44 \\
67 \\
84 \\
71 \\
8\end{array}$ & $\begin{array}{r}16.5 \\
25.2 \\
31.6 \\
26.7 \\
3.1\end{array}$ \\
\hline
\end{tabular}

Stiffness $=0.67 \times \mathrm{BUA}+0.28 \times \mathrm{SOS}-420$.

marker. Ethidium bromide was incorporated into the gel. The gels were directly photographed on a UV transilluminator and genotyped. Genotyping was performed twice in order to prevent genotyping error, and no differences were detected between the two analyses. The $P v u I I$ and $\mathrm{XbaI}$ polymorphic patterns of ER1 gene are shown in figure 1.

\section{Statistical Analysis}

Pearson correlation analysis was performed with QUS parameters as the dependent variables, and age, height, weight and BMI as the independent variables. Allele frequencies were calculated by the gene counting method, and the significant deviation from Hardy-Weinberg equilibrium was analyzed by the $\chi^{2}$ goodness test. Polymorphism information content was estimated by the methods of Botstein et al. [14]. Maximum likelihood estimates of haplotype frequencies were calculated by using expectation-maximization program, and the degree of nonrandom association was estimated by calculation of the delta between two polymorphic sites in the ER1 gene $[15,16]$. Categorical data was estimated by the $\chi^{2}$ independent test and quantitative data was analyzed by an unpaired t test or one-way ANOVA test. In the case of QUS pa-
Table 2. Pearson's correlation coefficient by linear regression analysis

\begin{tabular}{lcclr}
\hline Parameter & $\begin{array}{l}\text { BUA } \\
\text { dB/MHz }\end{array}$ & $\begin{array}{l}\text { BUA } \\
\text { T score }\end{array}$ & SOS, m/s & Stiffness \\
\hline Age, years & $-0.18^{* *}$ & $-0.23^{* * *}$ & 0.01 & -0.04 \\
Height, cm & 0.04 & 0.11 & -0.001 & 0.01 \\
Weight, kg & 0.05 & 0.11 & -0.004 & 0.01 \\
BMI, kg/m & 0.02 & 0.05 & -0.04 & -0.03 \\
\hline
\end{tabular}

Stiffness $=0.67 \times$ BUA $+0.28 \times$ SOS $-420 .{ }^{* *} \mathrm{p}<0.01 ;$ *** $\mathrm{p}<0.001$.

rameters, ANCOVA test was also performed with adjustment for potential confounding variables such as age and BMI values. In order to further investigate the influences of potential confounding variables such as age and BMI values, statistical analyses were also performed for each group after the subjects were divided into two groups by the median of age $(<52$ years or $\geq 52$ years) and BMI ( $<25$ or $\geq 25)$ values, respectively. All statistical significance was set at $\mathrm{p}=0.05$. All statistical analysis was performed using the SAS (version 8.1) computer program.

\section{Results}

\section{Clinical Characteristics of Study Subjects}

Demographic characteristics of the study subjects are given in table 1 . The average age of the subjects was 50.9 years, and the average BMI was 22.4. Pearson correlation analysis performed with QUS parameters showed a negative correlation between age and BUA at the calcaneus $(\mathrm{p}<0.01$, table 2).

\section{Genotype Distribution}

Electrophoretic patterns for two RFLPs in the ER1 gene are shown in figure 1. PCR reaction amplified a 1,300-bp DNA fragment including two polymorphic sites in the ER1 gene region. In the case of $X b a \mathrm{I}$ RFLP, the $\mathrm{X}$ allele yielded a 1,300-bp band, and the $\mathrm{x}$ allele gave bands of 900 and $400 \mathrm{bp}$, respectively. With respect to PvuII RFLP, the P allele indicated only a 1,300-bp band, while the $\mathrm{p}$ allele showed bands of 850 and $450 \mathrm{bp}$, respectively.

Genotype frequencies for $P v u I I$ and $X b a \mathrm{I}$ RFLPs were as follows: PP $11.6 \%, \mathrm{Pp} 47.2 \%$, pp $41.2 \%$, XX 1.2\%, Xx $24.4 \%$ and $x x 74.4 \%$. These polymorphisms were in HardyWeinberg equilibrium. The polymorphism information contents of these polymorphisms indicated the values of 0.3521 for PvuII RFLP and 0.2055 for XbaI RFLP. The dis- 
Table 3. ER1 gene polymorphisms in relation to age, BMI, BUA, SOS, and stiffness

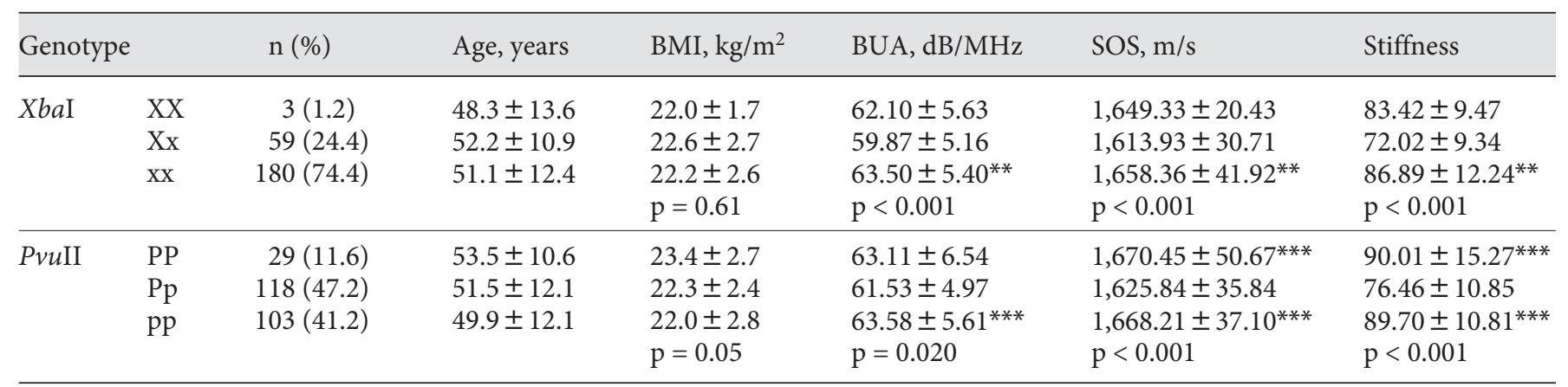

Stiffness: $0.67 \times$ BUA $+0.28 \times$ SOS $-420 .{ }^{* *} \mathrm{p}<0.05$ (vs. Xx group) from least significant difference test; ${ }^{* * *} \mathrm{p}<0.05$ (vs. Pp group) from least significant difference test.

Table 4. Relationship between two RFLPs in the ER1 gene and QUS parameters in the study group stratified by the median of age (52 years)

\begin{tabular}{|c|c|c|c|c|c|c|}
\hline Age & RFLP & Genotype & n (\%) & BUA, dB/MHz & $\mathrm{SOS}, \mathrm{m} / \mathrm{s}$ & Stiffness \\
\hline \multirow[t]{5}{*}{$<52$ years } & \multirow[t]{2}{*}{$X b a \mathrm{I}$} & $\mathrm{XX}+\mathrm{Xx}$ & $27(23.3)$ & $60.4 \pm 5.4$ & $1,618.8 \pm 35.4$ & $73.7 \pm 11.6$ \\
\hline & & $\mathrm{xx}$ & $89(76.7)$ & $\begin{array}{l}64.0 \pm 5.6 \\
p=0.004\end{array}$ & $\begin{array}{l}1,656.1 \pm 45.8 \\
p<0.001\end{array}$ & $\begin{array}{l}86.6 \pm 13.4 \\
p<0.001\end{array}$ \\
\hline & \multirow[t]{3}{*}{$P v u \mathrm{II}$} & PP & $12(9.8)$ & $64.3 \pm 5.5$ & $1,673.6 \pm 57.8^{* *}$ & $91.7 \pm 16.1^{* *}$ \\
\hline & & $\mathrm{Pp}$ & $56(45.9)$ & $61.8 \pm 5.4$ & $1,622.8 \pm 36.7$ & $75.8 \pm 11.4$ \\
\hline & & $\mathrm{pp}$ & $54(44.3)$ & $\begin{array}{l}64.4 \pm 5.6^{* *} \\
p=0.04\end{array}$ & $\begin{array}{l}1,670.0 \pm 39.9^{* *} \\
p<0.001\end{array}$ & $\begin{array}{l}90.7 \pm 11.7^{* *} \\
p<0.001\end{array}$ \\
\hline \multirow[t]{6}{*}{$\geq 52$ years } & \multirow[t]{2}{*}{ XbaI } & $X X+X x$ & $35(28.0)$ & $59.6 \pm 5.0$ & $1,613.2 \pm 27.7$ & $71.7 \pm 7.8$ \\
\hline & & $\mathrm{xx}$ & $90(72.0)$ & $\begin{array}{l}63.0 \pm 5.2 \\
p=0.001\end{array}$ & $\begin{array}{l}1,660.5 \pm 38.1 \\
p<0.001\end{array}$ & $\begin{array}{l}87.2 \pm 11.1 \\
p<0.001\end{array}$ \\
\hline & \multirow[t]{4}{*}{$P v u \mathrm{II}$} & $\mathrm{PP}$ & $17(13.4)$ & $62.3 \pm 7.2$ & $1,668.2 \pm 46.7^{* *}$ & $88.8 \pm 15.0^{* *}$ \\
\hline & & $\mathrm{Pp}$ & $62(48.8)$ & $61.3 \pm 4.6$ & $1,628.6 \pm 35.1$ & $77.1 \pm 10.3$ \\
\hline & & $\mathrm{pp}$ & $48(37.8)$ & $62.8 \pm 5.5$ & $1,666.1 \pm 34.4^{* *}$ & $88.6 \pm 9.9^{* *}$ \\
\hline & & & & $\mathrm{p}=0.345$ & $\mathrm{p}<0.001$ & $\mathrm{p}<0.001$ \\
\hline
\end{tabular}

Stiffness $=0.67 \times \mathrm{BUA}+0.28 \times \mathrm{SOS}-420 .{ }^{* *} \mathrm{p}<0.05$ (vs. Pp group) from least significant difference test.

tribution of haplotypes for both RFLPs was as follows: PX $13.1 \%$, Px $0.2 \%$, pX $22.6 \%$, px $64.1 \%$. There was also significant linkage disequilibrium between the two polymorphic sites studied $\left(\Delta=-0.2747 ; \mathrm{D}^{\prime}=-0.5210, \mathrm{p}<0.05\right)$.

\section{Association between Two Genetic Polymorphisms of} the ER1 Gene and Bone Phenotypes

We found significant associations between two RFLPs of the ER1 gene and QUS at the calcaneus. For the PvuII RFLP, subjects with pp genotype had significantly higher
BUA, SOS and SI values than those with Pp genotypes $(\mathrm{p}<0.05)$. In the case of the XbaI RFLP, subjects with an $\mathrm{xx}$ genotype had significantly higher BUA, SOS and SI values than those with $\mathrm{Xx}$ genotypes $(\mathrm{p}<0.05$, table 3$)$. These associations remain significant after adjusting for confounding factors, such as age and BMI values by ANCOVA test $(\mathrm{p}<0.05)$.

When study subjects were stratified by age-group, there were significant associations between the two polymorphisms in the ER1 gene and QUS parameters includ- 
Table 5. Relationship between two RFLPs in the ER1 gene and QUS parameters in the study group stratified according to BMI value

\begin{tabular}{|c|c|c|c|c|c|c|}
\hline BMI & RFLP & Genotype & n (\%) & BUA, dB/MHz & $\mathrm{SOS}, \mathrm{m} / \mathrm{s}$ & Stiffness \\
\hline \multirow[t]{7}{*}{$<25 \mathrm{~kg} / \mathrm{m}^{2}$} & \multirow[t]{3}{*}{$X b a \mathrm{I}$} & $\mathrm{XX}$ & $3(1.5)$ & $62.1 \pm 5.6$ & $1,649.3 \pm 20.4$ & $83.4 \pm 9.5$ \\
\hline & & $\mathrm{Xx}$ & $46(23.2)$ & $59.2 \pm 5.0$ & $1,615.5 \pm 32.1$ & $72.0 \pm 9.6$ \\
\hline & & $\mathrm{xx}$ & $149(75.3)$ & $63.5 \pm 5.4$ & $1,659.4 \pm 41.1$ & $87.2 \pm 12.2$ \\
\hline & \multirow[t]{4}{*}{$P v u \mathrm{II}$} & $\mathrm{PP}$ & $18(8.9)$ & $63.2 \pm 7.3$ & $1,682.1 \pm 43.3^{* *}$ & $93.4 \pm 14.2^{* *}$ \\
\hline & & $\mathrm{Pp}$ & $97(48.0)$ & $61.3 \pm 5.2$ & $1,627.9 \pm 35.4$ & $76.9 \pm 10.7$ \\
\hline & & $\mathrm{pp}$ & $87(43.1)$ & $63.6 \pm 5.6^{* *}$ & $1,668.5 \pm 39.4^{* *}$ & $89.8 \pm 11.6^{* *}$ \\
\hline & & & & $\mathrm{p}=0.019$ & $\mathrm{p}<0.001$ & $\mathrm{p}<0.001$ \\
\hline \multirow[t]{7}{*}{$\geq 25 \mathrm{~kg} / \mathrm{m}^{2}$} & \multirow[t]{3}{*}{$X b a \mathrm{I}$} & $X X+X x$ & $13(30.2)$ & $62.4 \pm 4.9$ & $1,608.5 \pm 25.4$ & $72.2 \pm 8.5$ \\
\hline & & $\mathrm{xx}$ & $30(69.8)$ & $63.6 \pm 5.3$ & $1,653.2 \pm 46.1$ & $85.5 \pm 12.7$ \\
\hline & & $\mathrm{p}$ & & $\mathrm{p}=0.493$ & $\mathrm{p}=0.002$ & $\mathrm{p}=0.001$ \\
\hline & \multirow[t]{4}{*}{$P v u \mathrm{II}$} & $\mathrm{PP}$ & $11(22.9)$ & $62.9 \pm 5.4$ & $1,651.4 \pm 57.9^{* *}$ & $84.5 \pm 16.0^{* *}$ \\
\hline & & $\mathrm{Pp}$ & $21(43.8)$ & $62.7 \pm 3.8$ & $1,616.3 \pm 37.1$ & $74.6 \pm 11.4$ \\
\hline & & $\mathrm{pp}$ & $16(37.8)$ & $63.7 \pm 6.0$ & $1,666.4 \pm 21.9^{* *}$ & $89.3 \pm 4.4^{* *}$ \\
\hline & & & & $p=0.818$ & $\mathrm{p}=0.001$ & $p=0.001$ \\
\hline
\end{tabular}

Stiffness $=0.67 \times$ BUA $+0.28 \times$ SOS $-420 .{ }^{* *} \mathrm{p}<0.05$ (vs. Pp group) from LSD test.

ing SOS and SI values measured in both groups, although an association between PvuII RFLP in the ER1 gene and BUA value in the age-group above 52 years did not reach statistical significance (table 4). These results were also similar to those in the group stratified by a BMI value of 25 (table 5). In the case of this, significant associations between two RFLPs in the ER1 gene and SOS and SI values were observed in both groups stratified by BMI values $(\mathrm{p}<0.05)$, but statistical significance with BUA value in the obese group (BMI above 25) was not observed.

\section{Discussion}

In the present study, we investigated the genotype distribution of two RFLPs (PvuII and XbaI) of the ER1 gene in Korean vegetarian men. Genotype distributions of the two RFLPs in the subjects were similar to those performed using other Korean postmenopausal subjects (for PvuII RFLP, PP 14.9\%, Pp 46.0\%, pp 39.1\%, $\chi^{2}=1.0308$, d.f. $=2, \mathrm{p}=0.5973$; for XbaI RFLP, XX 3.5\%, Xx 29.3\%, $\mathrm{xx} 67.2 \%, \chi^{2}=3.9352$, d.f. $=2, \mathrm{p}=0.1398$ ) [17].

When the relationship between $P v u I I$ and $X b a I$ RFLPs of the ER1 gene and QUS parameters was tested, we demonstrated that the two genetic polymorphisms ( $P v \mathrm{uII}$ and $X b a$ I RFLPs) were significantly associated with QUS at the calcaneus in Korean vegetarian men. In addition, these associations persisted after population stratification as well as after the adjustment of potential confounding factors such as age and BMI values by ANCOVA test, demonstrating significant associations irrespective of these parameters. This association indicates that the ER1 gene may influence bone quality, a genetic factor reflected by QUS at the calcaneus in both men and women. The precise mechanism for these associations is unclear, but some possibilities can be proposed.

First, because the two polymorphisms of the ER1 gene are located on intron 1 of this gene, they may affect gene expression and further, they may affect the interindividual susceptibility of the estrogen hormone through the regulation of mRNA transcription [9]. Another possibility is that these polymorphisms may be linked with unidentified polymorphisms associated with the quality or function of the protein encoded by the ER1 gene [9]. Further functional analysis is required to clarify our hypotheses.

In our study, the lowest QUS parameter values including BUA, SOS and SI were observed in heterozygotes compared to other genotypes. The reason for this remains unclear, but one possibility is that it is due to a molecular heterosis phenomenon [18]. A similar observation had been confirmed by Ushiyama et al. [19], who reported an association between two polymorphisms of the ER1 gene and osteoarthritis in the Japanese population. 
The degree of linkage disequilibrium between pairwise polymorphic sites may influence the results of association studies [20]. Strong linkage disequilibrium between the PvuII and $\mathrm{XbaI}$ polymorphic sites of the ER1 gene was detected in our study $(\mathrm{p}<0.05)$. This result was not unexpected because the two polymorphisms are separated by only $50 \mathrm{bp}$ [21] and located near one another [9]. Our findings from linkage disequilibrium data suggest that the haplotype occurrence of the two polymorphisms reduces the genetic diversity for linkage analysis [20], but provides an advantage for performing an association study [14-16]. Therefore, an association study may provide a better means than linkage analysis in our study design [14-16].

The limitations of our study include (a) relatively modest sample size, and thus, the possibility of type I error could not be completely excluded, and (b) the adherence to the significance level of $p<0.05$. Generally, in a study of complex phenotypes, such as asthma, obesity, non-insulin-dependent diabetes mellitus, essential hypertension and osteoporosis, it is necessary to adjust for the possibility of type I error by multiple tests.

\section{Conclusion}

We were able to show that the two genetic polymorphisms of the ER1 gene were significantly associated with QUS at the calcaneus in Korean vegetarian men. Nevertheless, our results are still preliminary. Therefore, further studies using a larger sample size are warranted to confirm the results of this study.

\section{References}

1 Pocock NA, Eisman JA, Hopper JL, Yeates MG, Sambrook PN, Eberl S: Genetic determinants of bone mass in adults: a twin study. J Clin Invest 1987;80:706-710.

2 Khaw KT, Reeve J, Luben R, Bingham S, Welch A, Wareham N, Oakes S, Day N: Prediction of total and hip fracture risk in men and women by quantitative ultrasound of the calcaneus: EPIC-Norfolk prospective population study. Lancet 2004;363:197-202.

-3 Riggs BL, Melton LJ 3rd: Involutional osteoporosis. N Engl J Med 1986;314:1676-1686.

-4 Lindsay R, Hart DM, Aitken JM, MacDonald EB, Anderson JB, Clarke AC: Long-term prevention of postmenopausal osteoporosis by oestrogen: evidence for an increased bone mass after delayed onset of oestrogen treatment. Lancet 1976;i:1038-1041.

5 Lufkin EG, Carpenter PC, Ory SJ, Malkasian GD, Edmonson JH: Estrogen replacement therapy: current recommendations. Mayo Clin Proc 1988;63:453-460.

6 Smith EP, Boyd J, Frank GR, Takahashi H, Cohen RM, Specker B, Williams TC, Lubahn DB, Korach KS: Estrogen resistance caused by a mutation in the estrogen-receptor gene in a man. N Engl J Med 1994;331:10561061.

7 Ponglikitmongkol M, Green S, Chambon P: Genomic organization of the human oestrogen receptor gene. EMBO J 1988;7:33853388 .
8 Kobayashi S, Inoue S, Hosoi T, Ouchi Y, Shi- 14 Botstein D, White RL, Skolnick M, Davis raki $\mathrm{M}$, Orimo $\mathrm{H}$ : Association of bone mineral density with polymorphism of the estrogen receptor gene. J Bone Miner Res 1996;11: 306-311.

RW: Construction of a genetic linkage map in man using restriction fragment length polymorphisms. Am J Hum Genet 1980;32: 314-331.

$\checkmark 9$ Boot AM, van der Sluis IM, de Muinck Keiz- $>15$ Hill WG, Robertson A: Linkage disequiliber-Schrama SM, van Meurs JB, Krenning EP, Pols HA, Uitterlinden AG: Estrogen receptor alpha gene polymorphisms and bone mineral density in healthy children and young adults. Calcif Tissue Int 2004;74:495-500.

10 Lau EM, Young RP, Lam V, Li M, Woo J: Estrogen receptor gene polymorphism and bone mineral density in postmenopausal Chinese women. Bone 2001;29:96-98.

11 Howard GM, Nguyen TV, Harris M, Kelly PJ, Eisman JA: Genetic and environmental contributions to the association between quantitative ultrasound and bone mineral density measurements: a twin study. J Bone Miner Res 1998;13:1318-1327.

12 Angus RM, Sambrook PN, Pocock NA, Eisman JA: A simple method for assessing calcium intake in Caucasian women. J Am Diet Assoc 1989;89:209-214.

13 van Daele PL, Burger H, Algra D, Hofman A, Grobbee DE, Birkenhager JC, Pols HA: Ageassociated changes in ultrasound measurements of the calcaneus in men and women: the Rotterdam Study. J Bone Miner Res 1994; 9:1751-1757. rium of finite populations. Theor Appl Genet 1968;38:226-231.

16 Lewontin RC: The interaction of selection and linkage. I. General considerations: heterotic models. Genetics 1964;49:49-67.

17 Nam HS, Shin MH, Kweon SS, Park KS, Sohn SJ, Rhee JA, Choi JS, Son MH: Association of estrogen receptor- $\alpha$ gene polymorphisms with bone mineral density in postmenopausal Korean women. J Bone Miner Metab 2005; 23:84-89.

18 Comings DE, McMurry JP: Molecular heterosis. Mol Genet Metab 2000;71:19-31.

19 Ushiyama T, Ueyama H, Inoue K, Nishioka J, Ohkubo J, Hukuda S: Estrogen receptor gene polymorphism and generalized osteoarthritis. J Rheumatol 1998;25:134-137.

20 Long JR, Zhang YY, Liu PY, Liu YJ, Shen H, Dvornyk V, Zhao LJ, Deng HW: Association of estrogen receptor alpha and vitamin D receptor gene polymorphisms with bone mineral density in Chinese males. Calcif Tissue Int 2004;74:270-276.

21 Yaich L, Dupont WD, Cavener DR, Parl FF: Analysis of the $P v u \mathrm{II}$ restriction fragmentlength polymorphism and exon structure of the estrogen receptor gene in breast cancer and peripheral blood. Cancer Res 1992;52: 77-83. 